\title{
The role of EGFR mutation as a prognostic factor in survival after diagnosis of brain metastasis in non-small cell lung cancer: a systematic review and meta-analysis
}

\author{
Wen-Ya Li ${ }^{1}$, Ting-Ting Zhao ${ }^{2}$, Hui-Mian $X_{u^{3}}$, Zhen-Ning Wang ${ }^{3}$, Ying-Ying $X_{u^{2}}$, Yunan Han ${ }^{2,4}$, Yong-Xi Song ${ }^{3}$,

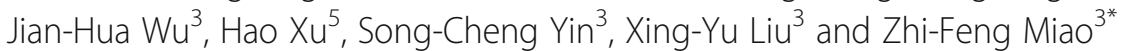

\begin{abstract}
Background: The brain is a common site for metastasis in non-small-cell lung cancer (NSCLC). This study was designed to evaluate the relationship between the mutational of the epidermal growth factor receptor (EGFR) and overall survival (OS) in NSCLC patients with brain metastases.

Methods: Searches were performed in PubMed, EmBase, and the Cochrane Library to identify studies evaluating the association of EGFR mutation with OS in NSCLC patients through September 2017.

Results: 4373 NSCLC patients with brain metastases in 18 studies were involved. Mutated EGFR associated with significantly improved OS compared with wild type. Subgroup analyses suggested that this relationship persisted in studies conducted in Eastern, with retrospective design, with sample size $\geq 500$, mean age of patients $\geq 65.0$ years, percentage male $<50.0 \%$, percentage of patients receiving tyrosine kinase inhibitor $\geq 30.0 \%$. Finally, although significant publication bias was observed using the Egger test, the results were not changed after adjustment using the trim and fill method.

Conclusions: This meta-analysis suggests that EGFR mutation is an important predictive factor linked to improved OS for NSCLC patients with brain metastases. It can serve as a useful index in the prognostic assessment of NSCLC patients with brain metastases.
\end{abstract}

Keywords: Lung cancer, EGFR, Brain metastasis, Prognosis, Meta analysis

\section{Background}

Lung cancer remains the leading cause of cancer-related deaths worldwide, and nearly $85 \%$ of lung patients are diagnosed with non-small-cell lung cancer (NSCLC) [1]. Despite continued efforts, innovations, and progress in diagnosis and treatment, the 5-year overall survival (OS) for patients with advanced NSCLC is only 15\% [2]. Over $25 \%$ of NSCLC patients present with brain metastases at diagnosis, and nearly $45 \%$ of autopsies of NSCLC patients show brain metastasis [3-5]. The median OS of lung cancer patients with brain metastases with no treatment

\footnotetext{
* Correspondence: zfmiao@cmu.edu.cn

${ }^{3}$ Department of Surgical Oncology, First Hospital of China Medical University, Shenyang 110001, Liaoning Province, China

Full list of author information is available at the end of the article
}

ranges from 4 to 11 weeks [5], while this can be prolonged to 14 months if they receive local treatments such as neurosurgery, stereotactic radiosurgery, or brain radiation therapy [6]. To best improve the OS and quality of life for patients receiving local treatments, selection of the optimal treatment option should be based on definite prognostic factors of each specific patient.

Genetic alterations of the epidermal growth factor receptor (EGFR) occur in approximately $20 \%$ of patients with lung adenocarcinomas in Western countries and 40-60\% in East Asia for [7-11]. Currently, tyrosine kinase inhibitors (TKIs) are widely used in NSCLC according to the EGFR mutation type. TKIs can reduce the incidence of long-term treatment failure in patients with or without brain metastases, possibly through EGFR 
signaling pathways promoting factors associated with oncogenic and metastatic progression such as angiogenesis, cellular proliferation, and epithelial mesenchymal transition [12, 13]. Although these relationships have been demonstrated, the association of EGFR mutation with OS in NSCLC patients with brain metastases remains controversial.

Several studies have illustrated that EGFR mutations are significantly associated with longer OS in NSCLC patients with brain metastases [14-19], yet numerous other studies show no association between EGFR mutations and OS for these patients [20-29]. Two studies have even suggested that EGFR mutations may decrease OS [30, 31]. Clarifying the relationship between EGFR and OS in NSCLC patients with brain metastases is particularly important, as it has not been definitively determined. Therefore, we conducted a meta-analysis of available studies to determine if a correlation exists between EGFR status and OS in NSCLC patients with brain metastases. The relationship was further quantitively probed in subpopulations of patients with specific characteristics using stratified analyses.

\section{Methods}

\section{Data sources, search strategy, and selection criteria}

This study was conducted and reported according to the meta-analysis of observational studies in epidemiology protocol [32]. Any observational study published in English and examining the relationship between EGFR status and OS in NSCLC patients with brain metastases was eligible for inclusion in our study, and no restrictions was placed on publication status (published, or in press). Briefly, we searched PubMed, EmBase, and Cochrane library for studies published up to September 2017 using the following search terms: ("brain metastases" OR "cerebral metastases" OR "neoplasm metastasis" OR "central nervous system" OR "encephalon") AND ("epidermal growth factor receptor" OR "receptor, epidermal growth factor" OR "EGFR" OR "EGFR mutation") AND ("lung" OR "pulmonary") AND ("neoplasms" OR "cancer" OR "carcinoma" OR "neoplasm") AND "human" AND "English". We also conducted manual searches of reference lists from all relevant original and review articles to identify additional eligible studies. Study title, study design, disease status, exposure, control, and outcome variables were used to identify relevant studies. All analyses were based on previously published studies; thus, no ethical approval or patient consent were required.

The literature search and study selection were independently undertaken by 2 authors using a standardized approach, and any inconsistencies were settled by the primary author until a consensus was reached. Studies were included in this meta-analysis if they met the following criteria: (1) Study design: study with prospective or retrospective observational design; (2) Participants: adult NSCLC patients ( $\geq 18$ years old) with brain metastases; (3) Exposure: EGFR mutations and wide-type; and (4) Outcomes: OS. Studies were excluded for the following reasons: (1) Participants with other disease; (2) patients with other histologies NSCLC; (3) No available data for statistics; or (4) Publication type was a review, comment, or letter to the editor.

\section{Data collection and quality assessment}

The following data from each study were extracted independently by two authors: first author's name, publication year, country, study design, disease stage, percentage of adenocarcinoma, sample size, mean age, percentage male, percentage smokers, percentage TKI, and OS. Any disagreements were resolved by a consensus. We also utilized a 9-star system using the Newcastle-Ottawa Scale (NOS) for assessing the quality of the observational studies based on selection (4 items), comparability ( 1 item), and outcome (3 items) [33]. We regarded a study with a score $\geq 7$ as being of high quality.

\section{Statistical analysis}

We examined the relationship between EGFR status and OS for NSCLC patients with brain metastases based upon hazard ratios (HRs) and 95\% confidence intervals (CIs) published in each study. The random-effects model was employed to calculate summary HRs and 95\% CIs for EGFR mutations versus EGFR wild-type for OS [34, 35]. Potential heterogeneity across the studies was examined using the Cochran's Q-statistic and $\mathrm{I}^{2}$ statistic [36, 37]. A sensitivity analysis was conducted by removing each individual study from the meta-analysis [38]. Meta-regression was performed to explore the source of heterogeneity based on percentage of adenocarcinoma, sample size, mean age, percentage male, percentage smokers, and percentage TKI [39]. Subgroup analyses were conducted based on country (Eastern versus Western), study design (prospective versus retrospective), disease status (adenocarcinoma versus both), sample size ( $\geq 500$ versus $<500$ ), mean age $(\geq 65.0$ versus $<65.0$ years), percentage male $(\geq 50.0 \%$ versus $<50.0 \%)$, percentage smokers $(\geq 50.0 \%$ versus $<50.0 \%)$, percentage of patients receiving TKIs $(\geq 30.0 \%$ versus $<30.0 \%$ ), and study quality (high versus low). The ratio between subgroups was calculated via the Chi-square test and meta-regression [39]. Publication bias was qualitatively evaluated using a funnel plot and quantitatively assessed using the Egger and Begg tests [40, 41]. All reported $P$ values are 2 -sided and $P$ values $<0.05$ are regarded as statistically significant for all included studies. Statistical analyses were conducting using STATA software (version 10.0; Stata Corporation, College Station, TX, USA). 


\section{Results}

Literature search

A total of 591 citations from PubMed, 681 citations from EmBase, and 119 citations from the Cochrane Library were identified, for a total of 1391 records. Of these, 1306 were excluded as duplicates or irrelevant studies. Eighty-five studies were selected for full-text assessment, of which 67 studies were excluded: 29 studies lacked sufficient data, 11 studies lacked appripriate controls, 23 studies reported patients with other disease, and 4 studies were reviews, comments, or letters to the editor. Finally, 18 studies were pooled into the meta-analysis [14-31]. The study selection process is presented in Fig. 1.

\section{Characteristics of selected studies}

Of the 18 included studies (encompassing a total of 4373 NSCLC patients with brain metastases), 3 had a prospective design $[18,26,30]$ and 15 had a retrospective design [14-17, 19-25, 27-29, 31]. Nine included studies were from Asia [14, 15, 17, 18, 20, 24-26, 31], and 9 were from Europe or America [16, 19, 21-23, 27-30]. All studies were published between 2009 and 2017, and 41-1127 patients were included in each study. Five studies included only patients with lung adenocarcinoma [14, 18, 20, 22, 26], while the other studies included various types of lung cancers [15-17, 19, 21, $23-25,27-31]$. The mean age of included patients ranged from 55.0-67.0 years, percentage male ranged from 28.3 to $66.2 \%$, percentage smokers ranged from 21.9 to $77.4 \%$, and percentage of patients receiving TKI ranged from 5.1 to $44.0 \%$. Study quality was assessed using the NOS, and 4 studies scored 8 [19,

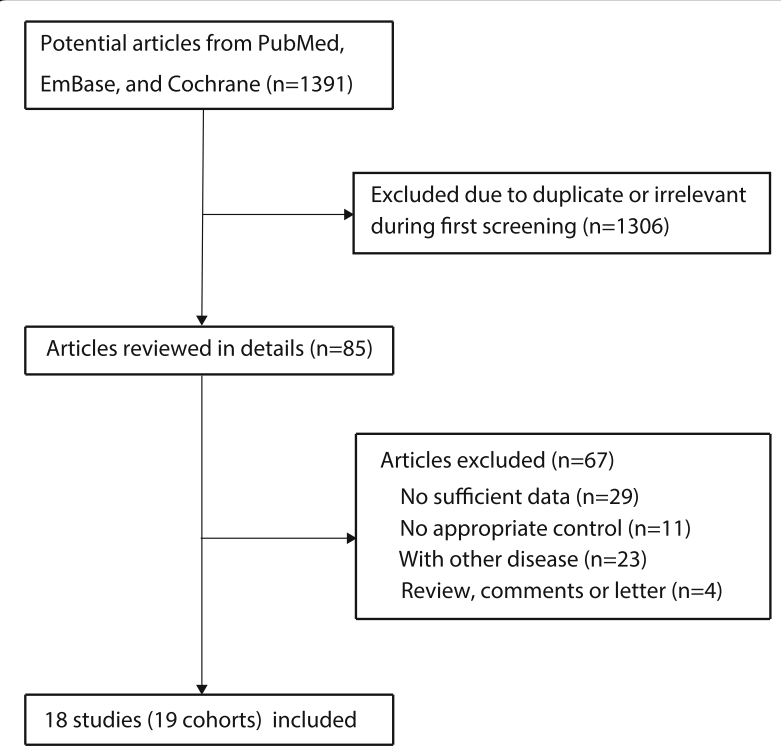

Fig. 1 Flow diagram of the study selection process
20, 22, 23], 5 studies scored 7 [14-16, 25, 26], 5 studies scored $6[21,27,28,30,31]$, and the remaining 4 studies scored $5[17,18,24,29]$. The general characteristics of the included studies are presented in Table 1.

\section{Meta-analysis}

After pooling all included studies, a statistically significant improvement in OS was found for NSCLC patients with brain metastases with EGFR mutations compared with wild-type EGFR (HR: 0.73; 95\% CI: 0.54-0.99; $P=0.045$; Fig. 2). Substantial heterogeneity was detected across the included studies $\left(\mathrm{I}^{2}=84.6 \%\right.$; $P<0.001)$, so we conducted a sensitivity analysis (Fig. 3 and Table 2). The results of the sensitivity analysis were consistent after excluding several studies $[21,22,25-27,31]$, with the magnitude of heterogeneity not significantly decreasing. However, when we excluded the study conducted by Arrieta et al. [30], the heterogeneity among the included studies decreased to $66.9 \%$ and EGFR mutations showed large improvement for OS (HR: 0.69; 95\% CI: 0.54-0.89; $P$ $=0.005)$. This study specifically included a lower percentage of adenocarcinoma, which may have contributed to lower incidence of EGFR mutations.

\section{Meta-regression and subgroup analyses}

The heterogeneity test showed a $P<0.05$, indicating that heterogeneity was statistically significant in the overall analysis. Therefore, a meta-regression analysis was conducted based on percentage of adenocarcinoma, sample size, mean age, percentage male, percentage smokers, and percentage receiving TKI to evaluate potential sources of heterogeneity. The results of the analysis are presented in Additional file 1. Overall, we noted that the percentage of patients receiving TKI might affect the relationship between EGFR status and OS in NSCLC patients with brain metastases $(P=$ $0.015)$, while percentage of adenocarcinoma $(P=0.279)$, sample size $(P=0.671)$, mean age $(P=0.112)$, percentage male $(P=0.275)$, and percentage smokers $(P=0.196)$ were all not significant factors contributing to this relationship.

The results of the subgroup analysis are listed in Table 3. Overall, we noted that EGFR mutations were associated with significantly improved OS in studies conducted in Eastern Countries (HR: 0.59; 95\% CI: $0.37-0.92 ; P=0.021)$ and in those with retrospective design (HR: 0.70; 95\% CI: 0.55-0.89; $P=0.004$ ), sample size $\geq 500$ (HR: 0.52 ; 95\% CI: $0.36-0.76 ; P=0.001$ ), mean age of included patients $\geq 65.0$ years (HR: 0.59 ; $95 \%$ CI: $0.36-$ 0.98; $P=0.043$ ), percentage male $<50.0 \%$ (HR: $0.60 ; 95 \%$ CI: $0.43-0.82 ; P=0.002)$, percentage receiving $\mathrm{TKI} \geq$ 30.0\% (HR: 0.60; 95\% CI: 0.48-0.75; $P<0.001$ ), and in studies with high quality (HR: $0.67 ; 95 \% \mathrm{CI}$ : 0.50-0.90; 
Table 1 Baseline characteristic of studies included in the systematic review and meta-analysis

\begin{tabular}{|c|c|c|c|c|c|c|c|c|c|c|c|}
\hline Author & $\begin{array}{l}\text { Publication } \\
\text { year }\end{array}$ & Country & Study design & $\begin{array}{l}\text { Disease } \\
\text { stage }\end{array}$ & $\begin{array}{l}\text { Percentage of } \\
\text { adenocarcinoma (\%) }\end{array}$ & $\begin{array}{l}\text { Sample } \\
\text { size }\end{array}$ & $\begin{array}{l}\text { Mean age } \\
\text { (years) }\end{array}$ & $\begin{array}{l}\text { Percentage } \\
\text { male (\%) }\end{array}$ & $\begin{array}{l}\text { Percentage } \\
\text { of smoker (\%) }\end{array}$ & $\begin{array}{l}\text { Percentage } \\
\text { of TKI (\%) }\end{array}$ & $\begin{array}{l}\text { NOS } \\
\text { score }\end{array}$ \\
\hline $\begin{array}{l}\text { Hsiao } \\
{[14]}\end{array}$ & 2013 & China & Retrospective & I-IV & 100.0 & 139 & NA & 41.0 & 30.0 & 32.0 & 7 \\
\hline Han [20] & 2016 & China & Retrospective & I-IV & 100.0 & 234 & NA & 53.4 & 44.0 & 30.3 & 8 \\
\hline $\begin{array}{l}\text { Russo } \\
{[21]}\end{array}$ & 2017 & Italy & Retrospective & IIIb-IV & 73.0 & 137 & 66.2 & 59.1 & 77.4 & NA & 6 \\
\hline Baek [15] & 2016 & Korea & Retrospective & IV & 70.0 & 259 & 68.0 & 64.5 & 59.1 & NA & 7 \\
\hline $\begin{array}{l}\text { Stanic } \\
{[22]}\end{array}$ & 2014 & Slovenia & Retrospective & I-IV & 100.0 & 629 & 64.0 & 51.8 & 72.0 & NA & 8 \\
\hline Hsu [16] & 2016 & Canada & Retrospective & IV & NA & 543 & 66.0 & 40.0 & NA & 41.0 & 7 \\
\hline $\begin{array}{l}\text { Hendriks } \\
\text { [23] }\end{array}$ & 2014 & $\begin{array}{l}\text { The } \\
\text { Netherlands }\end{array}$ & Retrospective & NA & 91.9 & 124 & 61.9 & 41.9 & 72.6 & 37.1 & 8 \\
\hline luchi [17] & 2014 & Japan & Retrospective & Ia-IV & 79.4 & 1127 & 67.0 & 65.2 & 64.2 & 42.3 & 5 \\
\hline $\begin{array}{l}\text { Arrieta } \\
{[30]}\end{array}$ & 2009 & Mexico & Prospective & IIIb-IV & 64.8 & 293 & 60.7 & 56.0 & 53.9 & 12.6 & 6 \\
\hline Lee [24] & 2012 & China & Retrospective & $|-|||$ & 93.0 & 43 & 59.0 & 53.0 & 37.0 & 44.0 & 5 \\
\hline luchi [18] & 2013 & Japan & Prospective & NA & 100.0 & 41 & NA & 29.3 & 21.9 & NA & 5 \\
\hline Li [25] & 2015 & China & Retrospective & NA & 83.8 & 136 & NA & 52.9 & 58.8 & 30.9 & 7 \\
\hline Luo [31] & 2013 & China & Retrospective & I-IV & 82.4 & 136 & 55.0 & 61.0 & 37.5 & 5.1 & 6 \\
\hline $\begin{array}{l}\text { Zhuang } \\
\text { [26] }\end{array}$ & 2013 & China & Prospective & I-IV & 100.0 & 54 & 61.7 & 42.6 & NA & 42.6 & 7 \\
\hline $\begin{array}{l}\text { Tomasini } \\
{[27]}\end{array}$ & 2016 & France & Retrospective & IV & 89.4 & 142 & 62.0 & 66.2 & 76.1 & NA & 6 \\
\hline $\begin{array}{l}\text { Eichler } \\
{[19]}\end{array}$ & 2010 & US & Retrospective & I-IV & 94.0 & 93 & 60.9 & 33.0 & 57.0 & 19.0 & 8 \\
\hline Mak [28] & 2015 & US & Retrospective & NA & NA & 172 & 60.0 & 45.0 & 70.0 & 42.0 & 6 \\
\hline $\begin{array}{l}\text { Wang } \\
{[29]}\end{array}$ & 2015 & US & Retrospective & $|-|||$ & 85.9 & 71 & 61.9 & 50.7 & NA & 21.1 & 5 \\
\hline
\end{tabular}

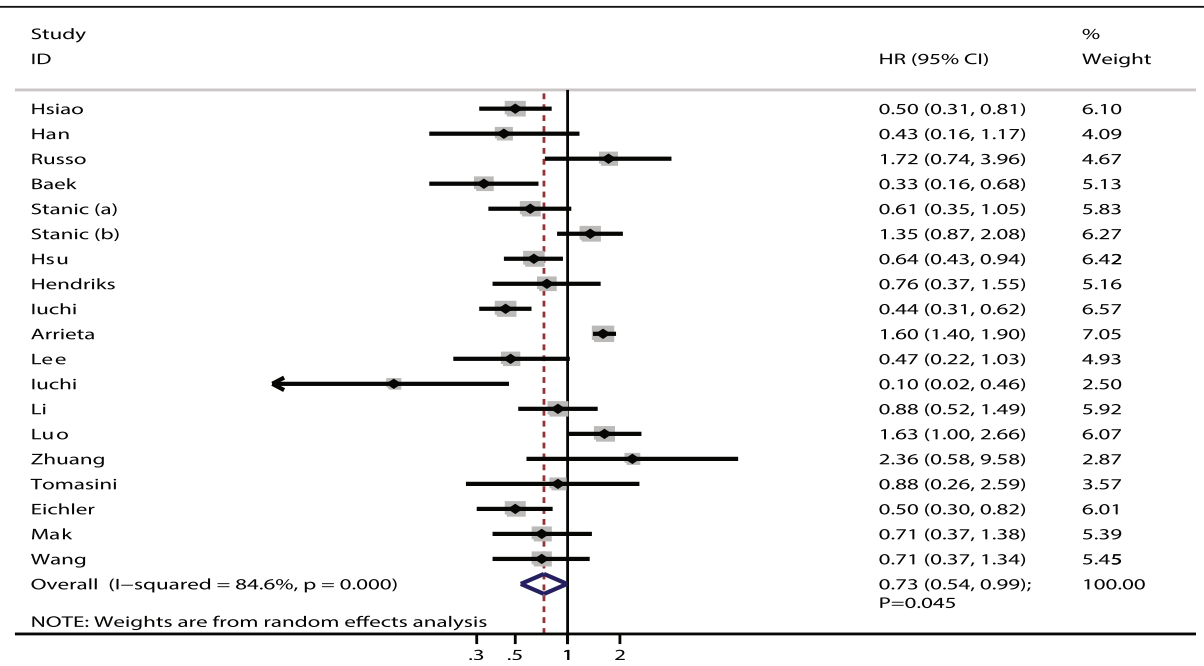

Fig. 2 Forest plot of the relationship between EGFR mutation and OS in NSCLC patients with brain metastases. Each study is shown by the point estimate of the $\mathrm{HR}$ and $95 \% \mathrm{Cl}$ (extending lines) 


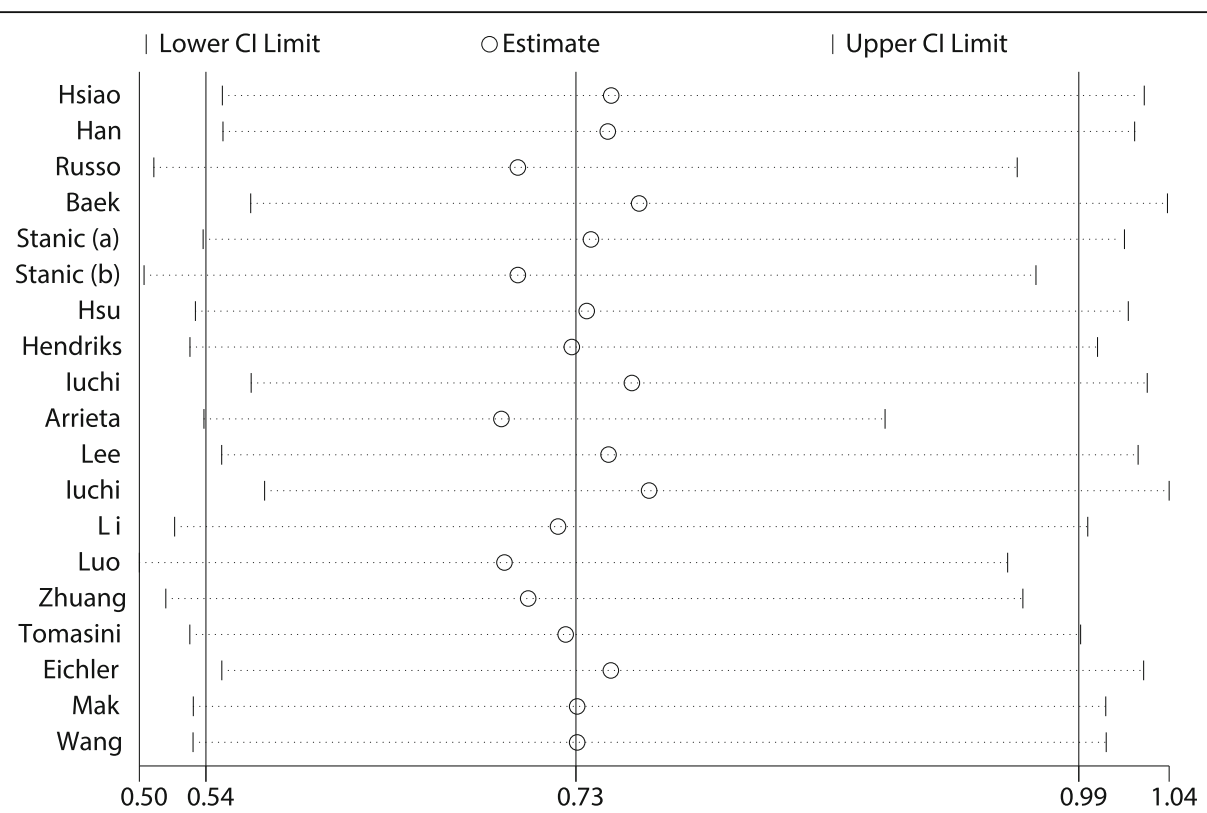

Fig. 3 Results of the sensitivity analysis. Results when each study is excluded are shown by the point estimate of the $\mathrm{HR}$ and $95 \% \mathrm{Cl}$ (extending lines)

$P=0.007)$. No other significant differences were detected based on other pre-defined factors. Furthermore, there was no evidence of a factor-specific difference in the HR for OS among patients with EGFR mutations compared to patients with wild-type EGFR (Table 3).

\section{Publication Bias}

Potential publication bias was detected via funnel plot (Fig. 4). Although the Begg test [41] showed no evidence of publication bias $(P=0.889)$, the Egger test [40] showed potential evidence of publication bias $(P=$

Table 2 Sensitivity analysis

\begin{tabular}{|c|c|c|c|c|}
\hline Excluding study & $\mathrm{HR}$ and $95 \% \mathrm{Cl}$ & $P$ value & Heterogeneity (\%) & $P$ value for heterogeneity \\
\hline Hsiao [14] & $0.75(0.55-1.03)$ & 0.073 & 84.3 & $<0.001$ \\
\hline Han [20] & $0.75(0.55-1.02)$ & 0.069 & 85.1 & $<0.001$ \\
\hline Russo [21] & $0.70(0.51-0.96)$ & 0.027 & 85.2 & $<0.001$ \\
\hline Baek [15] & $0.76(0.56-1.04)$ & 0.087 & 84.2 & $<0.001$ \\
\hline Stanic (a) [22] & $0.74(0.54-1.02)$ & 0.064 & 85.0 & $<0.001$ \\
\hline Stanic (b) [22] & $0.70(0.51-0.97)$ & 0.033 & 85.2 & $<0.001$ \\
\hline Hsu [16] & $0.74(0.53-1.02)$ & 0.065 & 84.7 & $<0.001$ \\
\hline Hendriks [23] & $0.73(0.53-1.00)$ & 0.052 & 85.4 & $<0.001$ \\
\hline luchi [17] & $0.76(0.56-1.03)$ & 0.076 & 81.8 & $<0.001$ \\
\hline Arrieta [30] & $0.69(0.54-0.89)$ & 0.005 & 66.9 & $<0.001$ \\
\hline Lee [24] & $0.75(0.55-1.02)$ & 0.070 & 85.0 & $<0.001$ \\
\hline luchi [18] & $0.77(0.57-1.04)$ & 0.089 & 84.3 & $<0.001$ \\
\hline Li [25] & $0.72(0.52-1.00)$ & 0.049 & 85.4 & $<0.001$ \\
\hline Luo [31] & $0.69(0.50-0.96)$ & 0.026 & 84.9 & $<0.001$ \\
\hline Zhuang [26] & $0.71(0.52-0.96)$ & 0.029 & 85.3 & $<0.001$ \\
\hline Tomasini [27] & $0.73(0.53-0.99)$ & 0.046 & 85.4 & $<0.001$ \\
\hline Eichler [19] & $0.75(0.55-1.03)$ & 0.073 & 84.4 & $<0.001$ \\
\hline Mak [28] & $0.73(0.53-1.01)$ & 0.056 & 85.3 & $<0.001$ \\
\hline Wang [29] & $0.73(0.53-1.01)$ & 0.056 & 85.3 & $<0.001$ \\
\hline
\end{tabular}


Table 3 Subgroup analyses

\begin{tabular}{|c|c|c|c|c|c|c|c|}
\hline Group & $\begin{array}{l}\text { Number of } \\
\text { cohorts }\end{array}$ & $\mathrm{HR}$ and $95 \% \mathrm{Cl}$ & $P$ value & $\begin{array}{l}\text { Heterogeneity } \\
(\%)\end{array}$ & $\begin{array}{l}P \text { value for } \\
\text { heterogeneity }\end{array}$ & $\begin{array}{l}\text { Ratio between } \\
\text { subgroups }\end{array}$ & $\begin{array}{l}\text { P value between- } \\
\text { subgroup }\end{array}$ \\
\hline \multicolumn{8}{|l|}{ Country } \\
\hline $\begin{array}{l}\text { Eastern } \\
\text { Countries }\end{array}$ & 9 & $0.59(0.37-0.92)$ & 0.021 & 76.3 & $<0.001$ & $0.68(0.38-1.21)$ & 0.189 \\
\hline $\begin{array}{l}\text { Western } \\
\text { Countries }\end{array}$ & 10 & $0.87(0.61-1.25)$ & 0.455 & 81.6 & $<0.001$ & & \\
\hline \multicolumn{8}{|l|}{ Study design } \\
\hline Prospective & 3 & $0.81(0.18-3.75)$ & 0.792 & 83.7 & 0.002 & $1.16(0.25-5.38)$ & 0.852 \\
\hline Retrospective & 16 & $0.70(0.55-0.89)$ & 0.004 & 64.7 & $<0.001$ & & \\
\hline \multicolumn{8}{|l|}{ Disease status } \\
\hline Adenocarcinoma & 6 & $0.65(0.36-1.18)$ & 0.154 & 75.5 & 0.001 & $0.86(0.43-1.72)$ & 0.660 \\
\hline Both & 13 & $0.76(0.53-1.10)$ & 0.152 & 86.7 & $<0.001$ & & \\
\hline \multicolumn{8}{|l|}{ Sample size } \\
\hline 500 or more & 2 & $0.52(0.36-0.76)$ & 0.001 & 49.4 & 0.160 & $0.68(0.41-1.10)$ & 0.117 \\
\hline$<500$ & 17 & $0.77(0.56-1.06)$ & 0.106 & 81.4 & $<0.001$ & & \\
\hline \multicolumn{8}{|l|}{ Mean age (years) } \\
\hline 65.0 or older & 4 & $0.59(0.36-0.98)$ & 0.043 & 73.2 & 0.011 & $0.65(0.35-1.19)$ & 0.160 \\
\hline$<65.0$ & 11 & $0.91(0.65-1.28)$ & 0.595 & 78.0 & $<0.001$ & & \\
\hline \multicolumn{8}{|l|}{ Percentage male (\%) } \\
\hline 50.0 or greater & 12 & $0.81(0.55-1.19)$ & 0.290 & 86.2 & $<0.001$ & $1.35(0.82-2.23)$ & 0.242 \\
\hline$<50.0$ & 7 & $0.60(0.43-0.82)$ & 0.002 & 42.9 & 0.105 & & \\
\hline \multicolumn{8}{|c|}{ Percentage of current/past smokers (\%) } \\
\hline 50.0 or greater & 11 & $0.78(0.52-1.17)$ & 0.239 & 87.5 & $<0.001$ & $1.50(0.64-3.50)$ & 0.349 \\
\hline$<50.0$ & 5 & $0.52(0.25-1.11)$ & 0.092 & 81.1 & $<0.001$ & & \\
\hline \multicolumn{8}{|c|}{ Percentage of patients using TKI (\%) } \\
\hline 30.0 or greater & 9 & $0.60(0.48-0.75)$ & $\begin{array}{l}< \\
0.001\end{array}$ & 26.2 & 0.211 & $0.59(0.32-1.10)$ & 0.099 \\
\hline$<30.0$ & 4 & $1.01(0.57-1.81)$ & 0.963 & 87.3 & $<0.001$ & & \\
\hline \multicolumn{8}{|l|}{ Study quality } \\
\hline High & 10 & $0.67(0.50-0.90)$ & 0.007 & 58.0 & 0.011 & $0.85(0.47-1.53)$ & 0.585 \\
\hline Low & 9 & $0.79(0.47-1.31)$ & 0.357 & 88.3 & $<0.001$ & & \\
\hline
\end{tabular}

$\mathrm{Cl}$ confidence intervals, $H R$ hazards ratios, $T K I$ tyrosine kinase inhibitor, bold entries $\mathrm{P}<0.05$

0.008). The results were not changed following adjustment with the trim and fill method (HR: 0.73; 95\% CI: 0.54-0.99; $P=0.045$ ) [42].

\section{Discussion}

Our meta-analysis analyzed 3 prospective studies and 15 retrospective studies to explore possible correlations between EGFR status and OS for NSCLC patients with brain metastases. The included 18 studies involved 4373 NSCLC patients with brain metastases. Our results support that mutated EGFR associates with significant improvement in OS compared with wild-type EGFR. Stratified analyses determined that a similar effect was seen in studies conducted in Eastern Countries and studies with retrospective design, sample size $\geq 500$, mean age of included patients $\geq 65.0$ years, percentage male $<50.0 \%$, percentage receiving $\mathrm{TKI} \geq 30.0 \%$, and studies with high quality.

The results were predominantly consistent with those of previous studies, which have demonstrated that EGFR mutations could prolong OS over wild-type EGFR. Hsiao et al. [14] suggested that EGFR mutation is an independent predictive factor for treatment response and OS in lung adenocarcinoma patients with brain metastases. They point out that radiation could induce nuclear translocation of wild-type, augmenting repair of DNA double-strand breaks in lung adenocarcinoma cells [43]. Alternatively, irradiation could delay DNA repair and decrease clonogenic survival in NSCLC cells with mutated EGFR [44, 45]. Baek et al. indicated that EGFR 


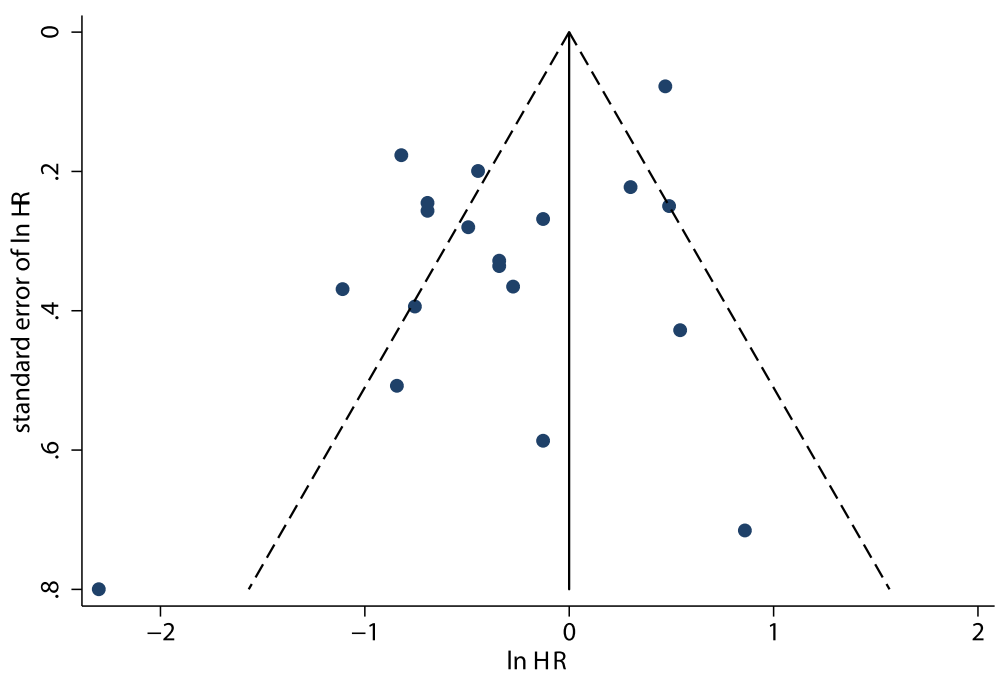

Fig. 4 Publication bias

mutation could increase incidence of brain metastases and improve OS in NSCLC patients with brain metastases. This significant improvement in OS was mainly observed if the brain is the first metastatic site [15]. Several other studies have demonstrated EGFR mutations to associate with an increased risk of brain metastases and prolonged survival after brain metastases in NSCLC patients [16-19]. A possible reason could be that EGFR-TKI could prevent brain metastases progression in NSCLC patients with activating EGFR mutations compared with those treated with conventional chemotherapy [46]. Further, different mechanisms and drug sensitivities between synchronous and metachronous brain metastases exist since metachronous brain metastases always accompany central nervous system symptoms while synchronous brain metastases are often asymptomatic.

Several studies included in our analysis reported inconsistent results. Numerous studies found that EGFR mutations could not predict survival or local control in NSCLC patients with brain metastases [20-29]. This lack of significant difference could be due to the studies being designed to evaluate the incidence of brain metastases or the treatment effects as primary endpoint. The sample size of these studies was smaller than expected, and broad 95\% CIs were found, leading to no statistically significant differences being found. In addition, Arrieta et al. suggested that EGFR expression significantly associated with worse OS, possibly due to the low frequency of EGFR expression [30]. Luo et al. suggested that median OS was 24.5 and 15.0 months in EGFR wild-type and mutant groups, respectively [31]. The major reason for this could be that the use of EGFR-TKI therapy after diagnosis of brain metastases was associated with longer survival $[47,48]$.
Subgroup analyses suggested that EGFR mutations were associated with improved OS in several subsets. The combined higher incidence of EGFR mutation and sufficient statistical power indicated a relationship between EGFR status and OS in NSCLC patients with brain metastases. Further, high percentages of patients using EGFR-TKI produced better effect on OS. This relationship was not observed in numerous subsets, and these conclusions may be unreliable since smaller cohorts were included. Therefore, we presented our relative results and provided a synthetic and comprehensive review.

Although this is not the first meta-analysis to evaluate the relationship between EGFR status and OS in NSCLC patients with brain metastases, this study has several strengths over the previous meta-analysis [49]. The main purpose of previous meta-analysis was to investigate the risk of brain metastases in EGFR mutations or wild type, and secondary outcome was OS in NSCLC patients with brain metastases. They point out EGFR mutation patients was associated with an increased risk of brain metastases than those with wild type. Further, EGFR mutation prolonged OS in patients with brain metastases compared with wild-type EGFR. However, the result for NSCLC patients with brain metastases just based on 7 studies, and numerous studies were neglected. Furthermore, no stratified analyses were conducted based on confounding factors. The current quantitative meta-analysis included 18 studies involved 4373 NSCLC patients with brain metastases comprised a wide range of characteristics of patients and the results of stratified analyses according to country, study design, disease status, sample size, mean age, percentage male, percentage smokers, percentage of patients receiving TKIs, and study quality were calculated. 
The limitations of this study are as follows: (1) recursive partitioning analysis, Karnofsky Performance scale, activity of systemic disease, type of treatment, and disease status may be associated with OS in NSCLC with brain metastases, while these data were not available in mostly included studies or unable to conduct stratified analysis; (2) several other molecular alterations in central nervous system response to TKI therapy were not reported in mostly studies; (3) most included studies had a retrospective design, so recall and selection biases might affect the relationship found between EGFR status and OS; (4) publication bias is an inevitable problem since this study is based on published articles, and ongoing or unpublished studies were not included in this meta-analysis; and (5) inherent limitations are found in any meta-analysis using pooled data when individual data are not available.

\section{Conclusions}

The pooled results show that EGFR mutation is associated with a significant improvement in OS when compared with wild-type EGFR. Further, this relationship manifested in studies conducted in Eastern Countries and studies with retrospective design, sample size $\geq 500$, mean age of included patients $\geq 65.0$ years, percentage male $<50.0 \%$, percentage receiving $\mathrm{TKI} \geq 30.0 \%$, and high quality. Further large-scale prospective studies should be conducted to verify this relationship and explore this relationship in specific patient subsets, especially for broader implications of improved OS in patients with EGFR mutant brain metastases.

\section{Additional file}

Additional file 1: Figure S1. meta-regression based on percentage of adenocarcinoma $(P=0.279)$. Figure $\mathbf{S} 2$. meta-regression based on sample size $(P=0.671)$. Figure S3. meta-regression based on mean age $(P=0.112)$. Figure S4. meta-regression based on percentage male $(P=0.275)$. Figure $\mathbf{S 5}$. meta-regression based on percentage smokers $(P=0.196)$. Figure $\mathbf{S 6}$. meta-regression based on percentage of patients receiving TKI $(P=0.015)$. (DOCX $2864 \mathrm{~kb})$

\section{Abbreviations}

Cl: Confidence interval; EGFR: Epidermal growth factor receptor; HR: Hazard ratio; NOS: Newcastle-Ottawa Scale; NSCLC: Non-small-cell lung cancer; OS: Overall survival; TKI: Tyrosine kinase inhibitor

\section{Acknowledgements}

Abstract of this paper were submit to 2018 IASLC (International Association for the Study of lung Cancer) meeting, and exhibit as a poster. The abstract was published in https://doi.org/10.1016/j.jtho.2018.08.613.

\section{Funding}

This work was supported by the National Natural Science Foundation of China (No. 81272718, 81302125 and 81372550). The sponsors played no role in the study design, data collection, or analysis, or decision to submit the article for publication.

\section{Availability of data and materials}

All data generated or analysed during this study are included in this published article [and its Additional file 1].

\section{Authors' contributions}

WYL and ZFM designed this study. TTZ, YYX, YNH, YXS, JHW and HX collected and analyzed the data. SCY, WYL and ZFM drafted the manuscript. $X Y L, H M X$ and ZNW interpreted the data and revised the manuscript. All authors have read and approved the manuscript, acknowledged the abstract was submit to 2018 IASLC (International Association for The Study of Lung Cancer) meeting.

Ethics approval and consent to participate

Not applicable.

\section{Consent for publication}

Not applicable.

\section{Competing interests}

The authors declare that they have no competing interests.

\section{Publisher's Note}

Springer Nature remains neutral with regard to jurisdictional claims in published maps and institutional affiliations.

\section{Author details}

${ }^{1}$ Department of Thoracic Surgery, First Hospital of China Medical University, Shenyang, Liaoning Province, China. ${ }^{2}$ Department of Breast Surgery, First Hospital of China Medical University, Shenyang, Liaoning Province, China. ${ }^{3}$ Department of Surgical Oncology, First Hospital of China Medical University, Shenyang 110001, Liaoning Province, China. ${ }^{4}$ Division of Public Health Sciences, Department of Surgery, Washington University School of Medicine, Saint Louis, MO, USA. ${ }^{5}$ Department of Medical Oncology, Shengjing Hospital of China Medical University, Shenyang, Liaoning Province, China.

Received: 28 January 2018 Accepted: 30 January 2019

Published online: 13 February 2019

\section{References}

1. Siegel R, Naishadham D, Jemal A. Cancer statistics, 2012. CA Cancer J Clin. 2012;62:10-29.

2. Jemal A, Siegel R, Ward E, Hao Y, Xu J, Murray T, et al. Cancer statistics, 2008. CA Cancer J Clin. 2008;58:71-96.

3. Nussbaum ES, Djalilian HR, Cho KH, Hall WA. Brain metastases. Histology, multiplicity, surgery, and survival. Cancer. 1996;78:1781-8.

4. Taillibert $\mathrm{S}$, Le Rhun É. Epidemiology of brain metastases. Cancer Radiother. 2015:19:3-9.

5. Zimm S, Wampler GL, Stablein D, Hazra T, Young HF. Intracerebral metastases in solid-tumor patients: natural history and results of treatment. Cancer. 1981;48:384-94.

6. Won YK, Lee JY, Kang YN, Jang JS, Kang JH, Jung SL, et al. Stereotactic radiosurgery for brain metastasis in non-small cell lung cancer. Radiat Oncol J. 2015;33:207-16.

7. Shigematsu H, Lin L, Takahashi T, Nomura M, Suzuki M, Wistuba II, et al. Clinical and biological features associated with epidermal growth factor receptor gene mutations in lung cancers. J Natl Cancer Inst. 2005;97:339-46.

8. Dogan S, Shen R, Ang DC, Johnson ML, D'Angelo SP, Paik PK, et al. Molecular epidemiology of EGFR and KRAS mutations in 3,026 lung adenocarcinomas: higher susceptibility of women to smoking-related KRASmutant cancers. Clin Cancer Res. 2012;18:6169-77.

9. Sun Y, Ren Y, Fang Z, Li C, Fang R, Gao B, et al. Lung adenocarcinoma from east Asian never-smokers is a disease largely defined by targetable oncogenic mutant kinases. J Clin Oncol. 2010;28:4616-20.

10. Wu JY, Yu CJ, Chang YC, Yang CH, Shih JY, Yang PC. Effectiveness of tyrosine kinase inhibitors on "uncommon" epidermal growth factor receptor mutations of unknown clinical significance in nonsmall cell lung cancer. Clin Cancer Res. 2011;17:3812-21.

11. Wu YL, Lee JS, Thongprasert S, Yu CJ, Zhang L, Ladrera G, et al. Intercalated combination of chemotherapy and erlotinib for patients with advanced stage non-small-cell lung cancer (FASTACT-2): a randomised, double-blind trial. Lancet Oncol. 2013;14:777-86.

12. Lichtenberger BM, Tan PK, Niederleithner H, Ferrara N, Petzelbauer P, Sibilia M. Autocrine VEGF signaling synergizes with EGFR in tumor cells to promote epithelial cancer development. Cell. 2010;140:268-79. 
13. Yatabe $Y$, Takahashi T, Mitsudomi T. Epidermal growth factor receptor gene amplification is acquired in association with tumor progression of EGFRmutated lung cancer. Cancer Res. 2008;68:2106-11.

14. Hsiaoa SH, Lin HC, Chou YT, Lin SE, Kuo CC, Yu MC, et al. Impact of epidermal growth factor receptor mutations on intracranial treatment response and survival after brain metastases in lung adenocarcinoma patients. Lung Cancer. 2013;81:455-61.

15. Baek MY, Ahn HK, Park KR, Park HS, Kang SM, Park I, et al. Epidermal growth factor receptor mutation and pattern of brain metastasis in patients with non-small cell lung cancer. Korean J Intern Med. 2018;33:168-75.

16. Hsua F, Caluwe AD, Anderson D, Nichol A, Toriumi T, Ho C. EGFR mutation status on brain metastases from non-small cell lung cancer. Lung Cancer. 2016;96:101-7.

17. Luchi T, Shingyoji M, Itakura M, Yokoi S, Moriya $Y$, Tamura $H$, et al. Frequency of brain metastases in non-small-cell lung cancer, and their association with epidermal growth factor receptor mutations. Int J Clin Oncol. 2015;20:674-9.

18. Luchi T, Shingyoji M, Sakaida T, Hatano K, Nagano O, Itakura M, et al. Phase Il trial of gefitinib alone without radiation therapy for Japanese patients with brain metastases from EGFR-mutant lung adenocarcinoma. Lung Cancer. 2013;82:282-7.

19. Eichler AF, Kahle KT, Wang DL, Joshi VA, Willers $H$, Engelman JA, et al. EGFR mutation status and survival after diagnosis of brain metastasis in nonsmall cell lung cancer. Neuro-Oncology. 2010;12:1193-9.

20. Han G, Bi J, Tan W, Wei X, Wang $X$, Ying $X$, et al. A retrospective analysis in patients with EGFR-mutant lung adenocarcinoma: is EGFR mutation associated with a higher incidence of brain metastasis? Oncotarget. 2016;7: 56998-7010.

21. Russo A, Franchina T, Ricciardi GR, Fanizza C, Scimone A, Chiofalo G, et al. Influence of EGFR mutational status on metastatic behavior in nonsquamous non small cell lung cancer. Oncotarget. 2017;8:8717-25.

22. Stanic K, Zwitter M, Hitij NT, Kern I, Sadikov A, Cufer T. Brain metastases in lung adenocarcinoma: impact of EGFR mutation status on incidence and survival. Radiol Oncol. 2014;48:173-83.

23. Hendriks LE, Smit EF, Vosse BA, Mellema WW, Heideman DA, Bootsma GP, et al. EGFR mutated non-small cell lung cancer patients: more prone to development of bone and brain metastases? Lung Cancer. 2014;84:86-91.

24. Lee HL, Chung TS, Ting LL, Tsai JT, Chen SW, Chiou JF, et al. EGFR mutations are associated with favorable intracranial response and progression-free survival following brain irradiation in non-small cell lung cancer patients with brain metastases. Radiat Oncol. 2012;7:181.

25. Li H, Zhang X, Cao J, Su P, Lian J, Song X, et al. Exon 19 deletion of epidermal growth factor receptor is associated with prolonged survival in brain metastases from non-small-cell lung cancer. Tumour Biol. 2015;36: 9251-8.

26. Zhuang H, Yuan Z, Wang J, Zhao L, Pang Q, Wang P. Phase iistudy of whole brain radiotherapy with or without erlotinib in patients with multiple brain metastases from lung adenocarcinoma. Drug Des Devel Ther. 2013;7:1179-86.

27. Tomasini P, Serdjebi C, Khobta N, Metellus P, Ouafik L, Nanni I, et al. EGFR and KRAS mutations predict the incidence and outcome of brain metastases in non-small cell lung Cancer. Int J Mol Sci. 2016;17:E2132.

28. Mak KS, Gainor JF, Niemierko A, Oh KS, Willers H, Choi NC, et al. Significance of targeted therapy and genetic alterations in EGFR, ALK, or KRAS on survival in patients with non-small cell lung cancer treated with radiotherapy for brain metastases. Neuro-Oncology. 2015;17:296-302.

29. Wang TJC, Saad S, Qureshi YH, Jani A, Nanda T, Yaeh AM, et al. Does lung cancer mutation status and targeted therapy predict for outcomes and local control in the setting of brain metastases treated with radiation? Neuro-Oncology. 2015;17:1022-8.

30. Arrieta O, Saavedra-Perez D, Kuri R, Aviles-Salas A, Martinez L, MendozaPosada D, et al. Brain metastasis development and poor survival associated with carcinoembryonic antigen (CEA) level in advanced non-small cell lung cancer: a prospective analysis. BMC Cancer. 2009;9:119.

31. Luo D, Ye X, Hu Z, Peng K, Song Y, Yin $X$, et al. EGFR mutation status and its impact on survival of Chinese non-small cell lung cancer patients with brain metastases. Tumour Biol. 2014;35:2437-44

32. Stroup DF, Berlin JA, Morton SC, Olkin I, Williamson GD, Rennie D, et al. Meta-analysis of observational studies in epidemiology: a proposal for reporting. Meta-analysis of observational studies in epidemiology (MOOSE) group. JAMA. 2000;283:2008-12.

33. Wells G, Shea B, O'Connell D. The Newcastle-Ottawa Scale (NOS) for assessing the quality of nonrandomised studies in meta-analyses. Ottawa:
Ottawa Hospital Research Institute; 2009. Available: http://www.ohri.ca/ programs/clinical_epidemiology/oxford.htm. cited 2017 Apr 25.

34. DerSimonian R, Laird N. Meta-analysis in clinical trials. Control Clin Trials. 1986:7:177-88.

35. Ades $A E$, Lu G, Higgins JP. The interpretation of random-effects metaanalysis in decision models. Med Decis Mak. 2005;25:646-54.

36. Lau J, loannidis JP, Schmid CH. Quantitative synthesis in systematic reviews. Ann Intern Med. 1997;127:820-6.

37. Higgins JP, Thompson SG, Deeks JJ, Altman DG. Measuring inconsistency in meta-analyses. BMJ. 2003;327:557-60.

38. Tobias A. Assessing the influence of a single study in meta-analysis. Stata Tech Bull. 1999;47:15-7.

39. Altman DG, Bland JM. Interaction revisited: the difference between two estimates. BMJ. 2003;326:219.

40. Egger M, Davey Smith G, Schneider M, Minder C. Bias in meta-analysis detected by a simple, graphical test. BMJ. 1997;315:629-34.

41. Begg CB, Mazumdar M. Operating characteristics of a rank correlation test for publication bias. Biometrics. 1994;50:1088-101.

42. Duvall S, Tweedie R. A nonparametric "trim and fill" method for assessing publication bias in meta-analysis. J Am Stat Assoc. 2000;95:89-98.

43. Dittmann K, Mayer C, Fehrenbacher B, Schaller M, Raju U, Milas L, et al. Radiation-induced epidermal growth factor receptor nuclear import is linked to activation of DNA-dependent protein kinase. J Biol Chem. 2005; 280:31182-9.

44. Das AK, Sato M, Story MD, Peyton M, Graves R, Redpath S, et al. Non-small-cell lung cancers with kinase domain mutations in the epidermal growth factor receptor are sensitive to ionizing radiation. Cancer Res. 2006;66:9601-8.

45. Liccardi G, Hartley JA, Hochhauser D. EGFR nuclear translocation modulates DNA repair following cisplatin and ionizing radiation treatment. Cancer Res. 2011;71:1103-14.

46. Heon S, Yeap BY, Lindeman NI, Joshi VA, Butaney M, Britt GJ, et al. The impact of initial gefitinib or erlotinib versus chemotherapy on central nervous system progression in advanced non-small cell lung cancer with EGFR mutations. Clin Cancer Res. 2012;18:4406-14.

47. Eichler AF, Kahle KT, Wang DL, Joshi VA, Willers H, Engelman JA, et al. EGFR mutation status and survival after diagnosis of brain metastasis in cell lung cancer. Neuro-Oncology. 2010;12:1193-9.

48. Gow CH, Chien CR, Chang YL, Chiu YH, Kuo SH, Shih JY, et al. Radiotherapy in lung adenocarcinoma with brain metastases: effects of activating epidermal growth factor receptor mutations on clinical response. Clin Cancer Res. 2008;14:162-8.

49. Li L, Luo $\mathrm{S}$, Lin H, Yang H, Chen H, Liao Z, et al. Correlation between EGFR mutation status and the incidence of brain metastases in patients with nonsmall cell lung cancer. J Thorac Dis. 2017;9:2510-20.

Ready to submit your research? Choose BMC and benefit from:

- fast, convenient online submission

- thorough peer review by experienced researchers in your field

- rapid publication on acceptance

- support for research data, including large and complex data types

- gold Open Access which fosters wider collaboration and increased citations

- maximum visibility for your research: over $100 \mathrm{M}$ website views per year

At BMC, research is always in progress.

Learn more biomedcentral.com/submissions 